\title{
Intravarietal polymorphisms reveal possible common ancestor of native Schinus terebinthifolius Raddi populations in Brazil
}

\author{
J.V.C. Pinto', B.A. Crispim², A.A. Vasconcelos ${ }^{3}$, D. Geelen ${ }^{4}$, A.B. Grisolia² and \\ M.C. Vieira ${ }^{1}$ \\ ${ }^{1}$ Programa de Pós-Graduação em Agronomia, Faculdade de Ciências Agrárias, \\ Universidade Federal da Grande Dourados, Dourados, MS, Brasil \\ 2Programa de Pós-Graduação em Ciência e Tecnologia Ambiental, \\ Faculdade de Ciências Exatas e Tecnologia, \\ Universidade Federal da Grande Dourados, Dourados, MS, Brasil \\ IIniciação Científica, Faculdade de Ciências Biológicas e Ambientais, \\ Universidade Federal da Grande Dourados, Dourados, MS, Brasil \\ ${ }^{4}$ Department of Plant Production, Faculty of Bioengineering, Ghent University, \\ Belgium \\ Corresponding author: J.V.C. Pinto \\ E-mail: jannavelasques@gmail.com
}

Genet. Mol. Res. 15 (1): gmr.15017477

Received August 19, 2015

Accepted October 16, 2015

Published January 8, 2016

DOI http://dx.doi.org/10.4238/gmr.15017477

ABSTRACT. Schinus terebinthifolius Raddi is a perennial native from Atlantic forest. It is of high ecological plasticity and is used in traditional medicine. Based on promising reports concerning its bioactivity, it was included as a species of great interest for distribution through the National Health System. A number of agronomic studies to guide its crop production are therefore underway. This study examined diversity and phylogenetic relationships among native $S$. terebinthifolius populations from different Brazilian ecosystems: Cerrado; sandbanks; dense rainforest; and deciduous forest. The intergenic regions rpl20-5'rps12, trnH-psbA, and trnS-trnG were sequenced from cpDNA and aligned using BLASTn. There 
were few fragments for comparison in GenBank and so only region trnStrnG was informative. There were variations among and within populations with intravarietal polymorphisms and three distinct haplotypes (HpSM, $\mathrm{HpDDO}, \mathrm{HpNE}$ ), once populations from NE (sandbanks and rainforest) clustered together. Sequences from HpSM, HpNE, and HpDDO returned greater similarity to haplotypes A (AY928398.1), B (AY928399.1), and C (AY928400.1), respectively. A network, built by median-joining among native haplotypes and 10 available on GenBank, revealed HpSM as the origin of all other haplogroups. HpDDO showed the most mutations and was closely related to haplogroups from Argentina. While this could indicate hybridization, we believe that the polymorphisms resulted from adaptation to events such as deforestation, fire, rising temperature, and seasonal drought during the transition from Atlantic forest to Cerrado. While more detailed phylogeographical studies are needed, these results indicate eligible groups for distinct climates as an important step for prebreeding programs before field propagation.

Key words: Brazilian peppertree; Schinus terebinthifolius; Medicinal plant; Haplotypes; Population genetics

\section{INTRODUCTION}

Brazil is one of the most biodiverse countries on the planet. With around 45,000 documented plant species, its floristic complexity prevents an accurate knowledge of all available natural resources. When considering native medicinal plants the scenario is even more complex; despite knowledge of traditional peoples, very few species have been formally evaluated for therapeutic potential. Furthermore, very little is known of genetic diversity, dispersion patterns and chemotype differences, in the context of genotype selection for pre-breeding programs and effective inclusion in the production chain (de Albuquerque et al., 2007; Ribeiro et al., 2014).

As a strategy to encourage exploitation and inclusion of medicinal plants in family farming, the Ministry of Health of Brazil established the National Program for Medicinal Plants and Herbal Medicines, and listed 71 species of particular interest to the National Health System. Among these is the Brazilian peppertree (Schinus terebinthifolius Raddi - Anacardiaceae). It is a perennial shrub from Atlantic Forest and is dispersed throughout several ecosystems, from the south of Pernambuco to the State of Rio Grande do Sul, and also naturally occurs in Uruguay, Paraguay, and northern Argentina (Williams et al., 2005; Lorenzi, 2008; Brasil, 2009).

The Brazilian peppertree is a dioecious plant and its main pollinators are bees, wasps and some dipterans. Its abundant, vibrant, and sweet red fruits are also appreciated by birds and rodents, which both play an important role in seed dispersal. The traditional people of Brazil use its bark, leaves and fruits as anti-inflammatory, antipyretic, analgesic, and purifying agents. Owing to its ecoplasticity, the species is now widely distributed through different continents (Lenzi et al., 2003; Lenzi and Orth, 2004; Jesus and Monteiro Filho, 2007; Sühs et al., 2009; Cesário and Gaglianone, 2013).

The dispersion patterns of Brazilian peppertree are not yet elucidated, but appear to play 
an important role in distinction of chemotypes with pharmacological differences. It is known that the dispersion patterns of the species also influence population dynamics and tropical trees are very sensitive to ecological factors that favor their aggregation in family structure. However, a lack of evolutionary comprehension has also hindered the selection of stable genotypes for cropping systems and to supply the pharmaceutical industry (Hardy et al., 2006; Barbosa et al., 2007; Santos et al., 2007; Avise, 2009; Gundziza et al., 2009).

In recent years, phylogeography has helped to elucidate the effects of these changes on the genetic structure of plants. Phylogeography enables the study of the correlation between geographical distribution of haplotypes and their genealogical links, based on variabilities detected on the conserved genome of uniparental inheritance, low rates of mutation, and null recombination. Thus, the use of molecular tools may help us to understand the movements and dispersal patterns of colonizing species. For tree species, for example, the establishment of pioneer colonies mainly occurs by seed dispersion, a process that leaves footprints or maternal spots that can be detected by genetic markers of maternal inheritance.

Chloroplasts from angiosperms are organelles of maternal inheritance dispersed by seed but not by pollen. Their genetic structure is strongly influenced by the history of gene flow among populations, and by geological events such as climate change and ice ages. Chloroplasts are also considered to be of high genetic heterogeneity. Polymorphic sites can be found when performing sequence analysis of cpDNA, as is also the case for the mitochondrial genome. Variations in cpDNA can be classified into intravarietal polymorphisms, i.e., variations in sequences within a variety, subspecies or cultivar; and inter-subspecific polymorphisms, which are the variations found between different varieties of one species (Petit et al., 2004; Tang et al., 2004; Hastings et al., 2005; Yang et al., 2010; Khan and Azim, 2011).

There is a real need for information to provide a relevant selection of Brazilian pepper genotypes for pre-breeding programs in order to define strategies for germplasm conservation. With this in mind, the main objectives of this study were to: characterize intravarietal polymorphisms between sequenced populations of $S$. terebinthifolius; study population diversity and differentiation; reveal haplotypic groups from different Brazilian ecosystems; and build up a haplotype network including sequences available in GenBank, and search for ancestral connections that may help to elucidate dispersion patterns.

\section{MATERIAL AND METHODS}

\section{Plant material and DNA extraction}

Different accessions from five Brazilian ecosystems were randomly chosen (Table 1). Leaf samples were from a cryopreserved collection of the Laboratory of Medicinal Plants of Universidade Federal da Grande Dourados and had been previously collected in situ. Total DNA was extracted from leaf samples using a modified methodology of Doyle and Doyle (1991).

\section{Plastidial DNA (cpDNA) markers}

Three molecular markers from plastidial DNA were used, representing the following intergenic regions: $\operatorname{trnH}$ (GUG)-psbA; trnS (GCU)-trnG (UCC); and rpl20-5'rps12, according to Hamilton (1999) (Table 2). 
Table 1. Populations of Schinus terebinthifolius in Brazilian ecosystems collected for phylogeny studies of polymorphisms from intergenic regions.

\begin{tabular}{|c|c|c|c|c|c|c|c|c|}
\hline G & Origin & Ecosystem & Latitude S & Longitude W & Altitude $(\mathrm{m})$ & Climate & $\mathrm{PI}(\mathrm{mm})$ & $\mathrm{T}^{\circ} \mathrm{C}$ \\
\hline ES & São Mateus, ES & DRF & $18^{\circ} 43^{\prime} 00^{\prime \prime}$ & $39^{\circ} 51^{\prime} 31^{\prime \prime}$ & 38 & Aw & 1313 & 24.1 \\
\hline SM & Santa Maria, RS & DF & $29^{\circ} 41^{\prime} 02^{\prime \prime}$ & $53^{\circ} 48^{\prime} 25^{\prime \prime}$ & 151 & $\mathrm{Cfa}$ & 1617 & 18.8 \\
\hline ITA & Vera Cruz, BA & Sandbanks & $12^{\circ} 57^{\prime} 32^{\prime \prime}$ & $38^{\circ} 36^{\prime} 16^{\prime \prime}$ & 13 & Af & 1874 & 25.1 \\
\hline MSP & Cairú, BA & Sandbanks & $13^{\circ} 23^{\prime} 22^{\prime \prime}$ & $38^{\circ} 54^{\prime} 36^{\prime \prime}$ & 19 & Af & 2151 & 25.3 \\
\hline DDO & Dourados, MS & Cerrado & $22^{\circ} 13^{\prime} 15^{\prime \prime}$ & $54^{\circ} 48^{\prime} 21^{\prime \prime}$ & 430 & Cwa & 1400 & 23.6 \\
\hline
\end{tabular}

$\mathrm{G}$ = genotype; $\mathrm{BA}=$ Bahia; $\mathrm{ES}=$ Espírito Santo; $\mathrm{MS}=$ Mato Grosso do Sul; RS = Rio Grande do Sul; DRF = dense rainforest; $\mathrm{DF}=$ decidual forest; $\mathrm{S}=$ south, $\mathrm{W}=$ west; $\mathrm{PI}=$ pluviometric index; $\mathrm{Aw}=$ tropical wet and dry; $\mathrm{Cfa}=$ warm temperate; $\mathrm{Af}=$ tropical rainforest; $\mathrm{Cwa}=$ warm temperate.

Table 2. Sequences of primers, fragment lengths $(\mathrm{bp})$ and anneling temperature of markers used in polymorphism studies of Schinus terebinthifolius.

\begin{tabular}{llcc}
\hline Region & Primer $\left(5^{\prime}-3^{\prime}\right)$ & Fragment $(\mathrm{bp})$ & $\mathrm{T}\left({ }^{\circ} \mathrm{C}\right)$ \\
\hline $\operatorname{trnH}(\mathrm{GUG})$-psbA & F: ACTGCCTTGATCCACTTGGC & 495 & 56 \\
trns (GCU)-trnG (UCC) & R: CGAAGCTCCATCTACAAATGG & 844 & 52 \\
& F: GCCGCTTAGTCCACTCAGC & & 50 \\
Rpl20-5'rps12 & R: GAACGAATCACACTTTTACCAC & 884 & 50 \\
& F: TTTGTTCTACGTCTCCGAGC & & \\
\hline
\end{tabular}

After standardization, polymerase chain reactions (PCRs) were carried out in final volumes of $25 \mu \mathrm{L}$ (Table 3).

Table 3. Volume $(\mu \mathrm{L})$ of reagents in PCRs per intergenic marker used in polymorphism studies of Schinus terebinthifolius.

\begin{tabular}{lccc}
\hline Reagent & trnH-psbA & trnS-trnG & rpl20-5'rps12 \\
\hline Primer F & 1.5 & 1.0 & 1.5 \\
Primer R & 1.5 & 1.0 & 1.5 \\
PCR master mix & 12.5 & 12.5 & 12.5 \\
Taq DNA polimerase & 0.2 & 0.2 & 0.2 \\
$\mathrm{MgCl}_{2}$ & 0.3 & - & - \\
Ultra-pure $\mathrm{H}_{2} \mathrm{O}$ & 7.0 & 8.3 & 7.3 \\
DNA & 2.0 & 2.0 & 2.0 \\
\hline
\end{tabular}

Cycling conditions for PCR were, for regions trnH-psbA and trnS-trnG: initial denaturation at $95^{\circ} \mathrm{C}$ for $3 \mathrm{~min} ; 40$ cycles of $95^{\circ} \mathrm{C}$ for $30 \mathrm{~s}$, annealing temperature (Table 2) for $1 \mathrm{~min}$, and extension at $72^{\circ} \mathrm{C}$ for $1 \mathrm{~min}$; and a final extension at $72^{\circ} \mathrm{C}$ for $10 \mathrm{~min}$. For region rpl20-5'rps $12, \mathrm{PCR}$ conditions were initial denaturation at $96^{\circ} \mathrm{C}$ for $5 \mathrm{~min} ; 40$ cycles at $96^{\circ} \mathrm{C}$ for $45 \mathrm{~s}, 50^{\circ} \mathrm{C}$ for $1 \mathrm{~min}$, and extension at $72^{\circ} \mathrm{C}$ for $30 \mathrm{~s}$; and a final extension at $72^{\circ} \mathrm{C}$ for $10 \mathrm{~min}$. Amplified products were observed by electrophoresis on $2 \%$ agarose $(\mathrm{w} / \mathrm{v})$ gels treated with ethidium bromide. Fragment purification was performed using a phenol:chloroform protocol (Nath et al., 1993).

\section{Sequences and statistical analysis}

Sequencing was performed using an automated ABI 3500 (Applied Biosystems, Foster City, CA, USA) and the original primers. The quality of electropherograms was evaluated and edited in the BioEdit software. Consensus sequences were obtained using the CAP3 software 
(Huang and Madan, 1999), and local alignment (BLASTn) was performed using the NCBI database to identify similar sequences. Multiple alignments were performed using ClustalW, and the MEGA 6.0 software was used to calculate the genetic distance and build a dendrogram by neighborjoining with p-distance substitution. Sequences were characterized by the number of haplotypes, haplotype diversity, and nucleotides within and among populations.

\section{RESULTS}

Sequencing of the intergenic regions using plastid markers from Hamilton (1999) made it possible to detect variation among accessions of $S$. terebinthifolius and revealed polymorphisms among native populations in distinct ecosystems and also differences when compared with the sequences from other countries available in GenBank. The number of accessions amplified for each marker is shown in Table 4.

\begin{tabular}{|c|c|c|c|}
\hline \multirow[t]{2}{*}{ Local } & \multicolumn{3}{|c|}{ Number of accessions/marker } \\
\hline & trnH-psbA & $\operatorname{trnS}-\operatorname{trnG}$ & rpl20-5'rps 12 \\
\hline Dourados (MS) & 3 & 3 & 3 \\
\hline Vera Cruz (BA) & 4 & 4 & 5 \\
\hline Cairú (BA) & 4 & 3 & 4 \\
\hline Santa Maria (RS) & 4 & 4 & 4 \\
\hline São Mateus (ES) & 5 & 5 & 5 \\
\hline Total & 20 & 19 & 21 \\
\hline
\end{tabular}

Fragments from the trnH-psbA region returned sequences of $473 \mathrm{bp}$. Sequences from Vera Cruz-BA, Cairú-BA, Santa Maria-RS, and São Mateus-ES were identical, while sequence from Dourados-MS (Cerrado) revealed inter-subspecific polymorphism [SNP A (G)] in position 341 (Figure 1A). When aligned by BLASTn, native sequences returned $99 \%$ similarity to an accessions available on GenBank (GU135324.2) collected in Florida-US. All native sequences showed a polymorphism $[A(G)]$ at position 460. Accessions from Dourados-MS also showed a polymorphism in position 341.

Amplified sequences from rpl20-5'rps12 region returned 785 bp. Again, sequences were identical with the exception of Dourados-MS, which showed another inter-subspecific polymorphism [SNP A (C)] in position 235 (Figure 1B). As there were no sequences of this intergenic region of Brazilian peppertree available on GenBank, the BLASTn alignment returned greater similarity (97\%) to Mangifera indica (FJ937751.1 and FJ937752.1).

Fragments from region trnS-trnG returned sequences of 736 bp to Santa Maria-RS, and 739 to other accessions. BLASTn sequences revealed great similarity with haplotypes A (AY928398.1), B (AY928399.1), and C (AY928400.1) of S. terebinthifolius (Williams et al. 2005). Accessions from Santa Maria-RS returned similarity (99\%) with haplotype A; those from Dourados with haplotype C (99\%) and the others with haplotype B (99\%).

When aligned to those by Williams et al. (2005), native sequences showed two insertions/ deletions of cytokines at the same positions (between 253 and 255), and a polymorphism A (G) at position 293. In addition, sequences from Vera Cruz-BA, Cairú-BA and São Mateus-ES showed a polymorphism $T(G)$ in positions 30 and 243 , in comparison with sequences from haplotype $B$.

Comparisons among sequences from trnS-trnG region also revealed important variations among and within populations. Accessions from Santa Maria-RS aligned to other native sequences 
showed three deletions of adenines between positions 233 and 234, and a polymorphism $T(C)$ at position 459. Similarly, accessions from Dourados-MS had polymorphisms $A(C)$ at position 259, $\mathrm{T}(\mathrm{A})$ at position $369, \mathrm{C}(\mathrm{A})$ at position $567, \mathrm{G}(\mathrm{T})$ at position 597 , and $\mathrm{T}(\mathrm{C})$ at position 691 .

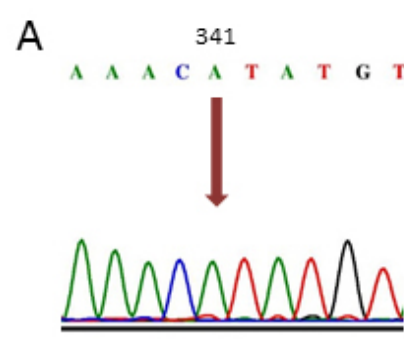

Dourados-MS

341

A A A

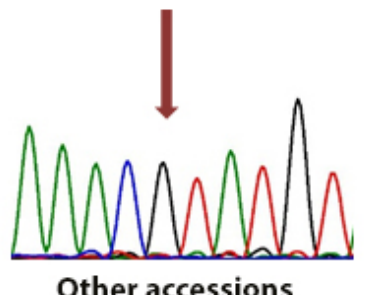

B

235

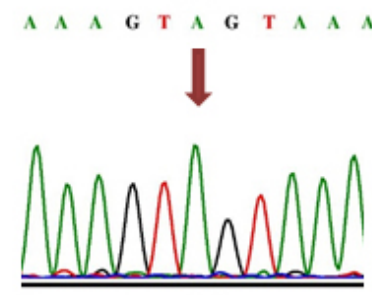

Dourados-MS

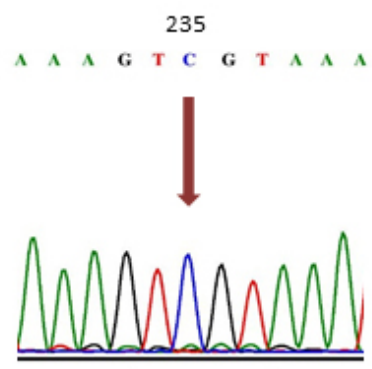

Other accessions

Figure 1. Electropherograms of SNPs. A. Inter-subspecific polymorphism [SNPA (G)] at position 341 from region trnHpsbA. B. Inter-subspecific polymorphism [SNP A (C)] at position 235 from region rpl20-rps12.

Concerning intravarietal variations, two accessions from São Mateus-ES showed a deletion of adenine at position 236, and one accession from Vera Cruz-BA had an insertion of adenine at position 237.

A comparison among three native haplotypes examined on this study to those from Williams et al. (2005) helped to build two networks, revealing Santa Maria-RS as a common ancestor (Figures 2 and 3). We used Network v.4.1.1.2 (Bandelt et al., 1999), and applied medianjoining methodology.

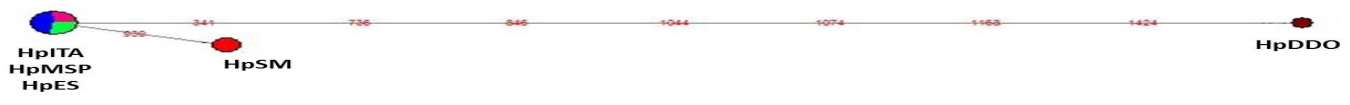

Figure 2. Haplotype network build-up based on intergenic sequences trnS-trnG from native accessions of Schinus terebinthifolius. HpITA (Vera Cruz-BA); HpMSP (Cairú-BA); HpES (São Mateus-ES); HpSM (Santa Maria-RS) and $H p D D O$ (Dourados-MS). 


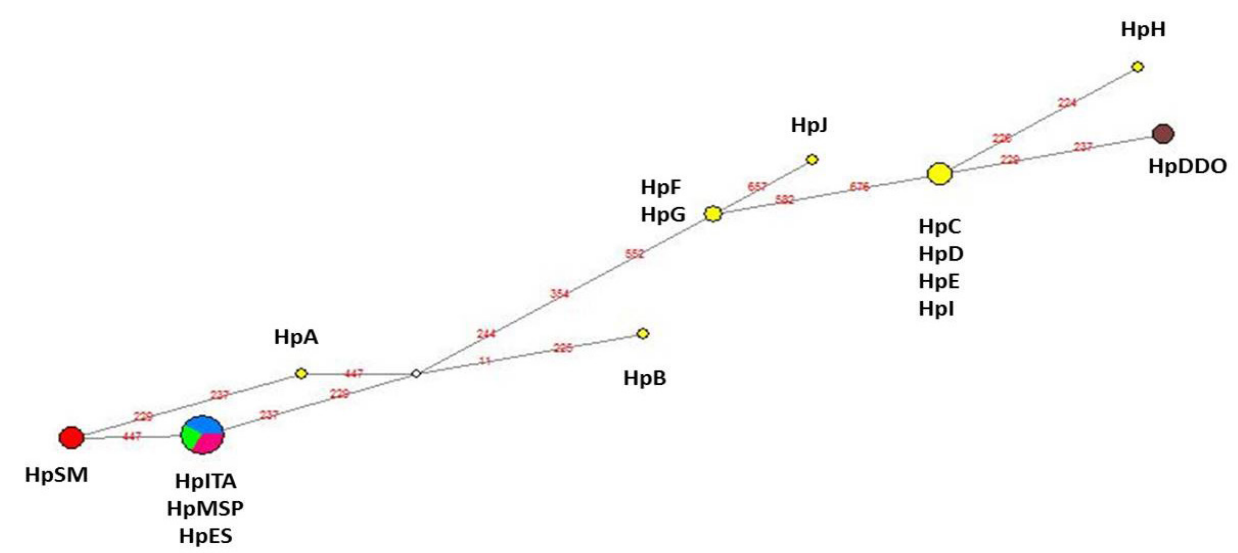

Figure 3. Haplotype network build up with Brazilian native accessions and accessions by Williams et al. (2005).

\section{DISCUSSION}

The analysis of plastidial DNA sequences of $S$. terebinthifolius using intergenic markers allowed the identification of genetic variations among populations from different ecosystems, and showed polymorphisms among native populations and significant differences compared to those available in GenBank.

The similarity (99\%) found among fragments from region trnH-psbA of native populations (Figure 1A) and sequences from Florida-USA (GU135324.2) may be an important indicative of ancestral colonizers. Indeed, previous studies by Williams et al. (2005) have also inferred two possible ancestors of Florida haplotypes from the South and Northeast of Brazil. Although the authors have used a different intergenic region, the congruence of results opens a precedent for future in-depth and comparative studies between both regions in order to understand dispersion patterns in that country, where $S$. terebinthifolius has become the main weed in agriculture fields (Williams et al., 2005; Cuda et al., 2006; Mukherjee et al., 2012).

Fragments amplified for rpl20-rps12 region were identical for all native sequences analyzed. However, accessions from Dourados-MS showed subspecific polymorphism, as seen in Figure 1B. Unfortunately, it was not possible to compare with accessions from other part of the globe because there are no sequences of $S$. terebinthifolius available for this marker; results from this study will be the first to be deposited in GenBank.

BLASTn alignment returned great similarity (97\%) with another Anacardiaceae, Mangifera indica (FJ937751.1 and FJ937752.1; Khan and Azim, 2011); which can be very informative in future evolutionary studies concerning differentiation among species in the same family group. Nevertheless, in this study for rpl20-rps12 region did not return relevant information.

Sequences from the intergenic trnS-trnG region were the most relevant in this study. Three distinct haplotypes were identified and helped to elucidate some phylogenetic questions.

When compared to sequences on GenBank, our accessions returned similarity with haplotypes from Florida-USA (Williams et al., 2005). Indeed, those authors draw this correlation with Brazilian ancestors, but a lack of native exemplars prevent them from tracing the native ancestor of haplotype B. Results of this study allow the inference that a common ancestor is from Northeast Brazil, given the similarity with sequences from Vera Cruz and Cairú-BA. 
The haplotype network shown in Figure 3, including all genotypes available for this intergenic region, strongly suggests that Santa Maria-RS (HpSM) is the original population and common ancestor of all others studied until now. From an evolutionary point of view, this information may support the understanding of recent dispersion and adaptation of Brazilian peppertree in the Northern hemisphere, where mean temperatures are lower than in Brazil.

The geographic isolation of a population is generally due to historical events, but the scope of a species changes once the accessions moves in space and starts the dispersion process. A species will generally keep its initial 'foothold' when introduced within the same climatic niche. However, after a period of evolutionary changes, it begins to disperse on new climate zones (Ridley, 2006; Jiménez-Valverde et al., 2011; Thompson et al., 2011).

Interestingly, accessions collected in Bahia and Espírito Santo grouped in a single haplotype (HpNE) and were closely related to HpSM, despite being from different ecogeographic regions with considerable soil and climate differences. These results corroborate the hypothesis of stratified dispersion of the Brazilian peppertree; this may involve both local spread around already-established populations, and also long distance jumps. This combination of dispersions has considerably increased the distances of expansion, and is used as the basis for a hypothesis for understanding the rapid advance of tree species following the last glaciation (Petit et al., 2004; Williams et al., 2007).

The fruits of Brazilian peppertree are much appreciated by birds and rodents, and some studies have reported a significant increase on germination rates of the seeds after ingestion by these animal species - strong evidence of their contribution to seed dispersion. However, we are far short of elucidating the course of these long distance dispersions or even explaining the evolutionary process that led to such ecoplasticity, although we recommend more detailed phylogeographic studies, and expansion of sample groups (Mandon-Dalger et al., 2004; Williams et al., 2007; Jesus and Monteiro Filho, 2007).

Perhaps the greatest contribution of accessing the origin population (Santa Maria-RS) is to understand the resistance of the species to low temperatures from the Northern hemisphere due to the existence of a common ancestor in an ecosystem characterized as deciduous forest, in subtropical climate, annual mean temperature of $18.8^{\circ} \mathrm{C}$, and winter mean of $6.9^{\circ} \mathrm{C}$. These results also help to elucidate recent data of Mukherjee et al. (2012), who found statistical trends in which species colonize areas with the lowest temperatures in the US, but contradict the theory of Gioeli and Langeland (2009), who argue that the species has limitations for cold tolerance that could be used in environmental control (Streck et al., 2011).

The most distant haplotype studied found in Dourados-MS (HpDDO) (Figure 3) showed ten mutational spots and a median vector from the source population (HpSM); this haplotype was closer to others from northern Argentina and characterized by Williams et al. (2005). Although it was collected in an area actually classified as Cerrado (Brazilian Savanah), a historical analysis shows that the same region has been under Atlantic Forest not more than a century ago. Therefore, it is possible to raise two hypotheses. First: the occurrence of intraspecific hybridization, which could only be proven with more detailed molecular analysis based on the development of microsatellite markers from parental sequences. Second: mutational spots have emerged as an adaptation response to ecological changes in this zone, especially during vegetation transition from Atlantic Forest to Cerrado, but also in response to a recent temperature rise due to deforestation and periodic burning practices that have already resulted in a decrease of water supply.

Due to their sedentary nature, plants can be strongly influenced by local selection, which often results in adaptation. This divergent selection may also result in reproductive isolation and 
ecological speciation. Despite its genetic basis not being completely understood, a local adaptation could be the result of changes in key loci, where some ancestral alleles present advantages in their home environment (antagonist pleiotropy). Alternatively, multiple independent loci could interact and induce local adaptation at organism level, for example, if certain alleles of loci were beneficial in a specific environment but neutral at different environments, and alleles at other loci showed an opposite pattern (Leimu and Fischer, 2008; Bomblies, 2010; Anderson et al., 2011).

Finally, we agree with Mukherjee et al. (2012) that the distribution of haplotypes in Brazil has niche standards performed with intraspecific competition between individuals, and that specific groups are better adapted to environmental conditions of its endemic area. Nevertheless, we propose that field experiments are needed for different areas of endemism of Brazilian peppertree, comparing multiple groups in each area to better understand the limitations that such environmental adjustments impose and, consequently, to select the promising genotypes for breeding programs.

\section{Conflicts of interest}

The authors declare no conflict of interest.

\section{ACKNOWLEDGMENTS}

The authors are thankful to Capes Foundation, CNPq, and to Fundect-MS for scholarships and research funding.

\section{REFERENCES}

Anderson JT, Willis JH and Mitchell-Olds T (2011). Evolutionary genetics of plant adaptation. Trends Genet. 27: 258-266. http://dx.doi.org/10.1016/j.tig.2011.04.001

Avise JC (2009). Phylogeography: retrospect and prospect. J. Biogeogr. 36: 3-15. http://dx.doi.org/10.1111/j.1365-2699.2008.02032.x Bandelt HJ, Forster P and Röhl A (1999). Median-joining networks for inferring intraspecific phylogenies. Mol. Biol. Evol. 16: 37-48. http://dx.doi.org/10.1093/oxfordjournals.molbev.a026036

Barbosa LCA, Demuner AJ, Clemente AD and Paula VF (2007). Seasonal variation in the composition of volatile oils from Schinus terebinthifolius Raddi. Quim. Nova 30: 1959-1965. http://dx.doi.org/10.1590/S0100-40422007000800030

Bomblies K (2010). Doomed lovers: mechanisms of isolation and incompatibility in plants. Annu. Rev. Plant Biol. 61: $109-124$. http://dx.doi.org/10.1146/annurev-arplant-042809-112146

Brasil (2009). Programa Nacional de Plantas Medicinais e Fitoterápicos. Ministério da Saúde, Secretaria de Ciência, Tecnologia e Insumos Estratégicos, Departamento de Assistência Farmacêutica e Insumos Estratégicos. Ministério da Saúde, Brasília.

Cesário LF and Gaglianone MC (2013). Pollinators of Schinus terebinthifolius raddi (Anacardiaceae) in vegetational formations of restinga in northern Rio de Janeiro state. Biosci. J. 29: 458-467.

Cuda JP, Ferriter AP, Manrique V and Medal JC (2006). Florida's Brazilian peppertree management plan. Recommendations from the Brazilian peppertree task force and Florida exotic pest plant council. Available at [http://www.fleppc.org/Manage_ Plans/2006BPmanagePlan5.pdf].

de Albuquerque UP, Muniz de Medeiros P, de Almeida AL, Monteiro JM, et al. (2007). Medicinal plants of the caatinga (semiarid) vegetation of NE Brazil: a quantitative approach. J. Ethnopharmacol. 114: 325-354. http://dx.doi.org/10.1016/j.jep.2007.08.017

Doyle JJ and Doyle JL (1991). Isolation of plant DNA from fresh tissue. Focus 1: 13-15.

Gioeli K and Langeland K (2009). Brazilian pepper-tree control. University of Florida, Cooperative Extension Service. Institute of Food and Agricultural Sciences, SS-AGR-17. Available at [http://edis.ifas.ufl.edu/aa219].

Gundziza M, Gweru N, Magwa ML, Mmbengwa V, et al. (2009). The chemical composition and biological activities of essential oil from the fresh leaves of Schinus terebinthifolius from Zimbabwe. Afr. J. Biotechnol. 8: 7164-7169.

Hamilton MB (1999). Four primer pairs for the amplification of chloroplast intergenic regions with intraspecific variation. Mol. Ecol. 8: 521-523. 
Hardy OJ, Maggia L, Bandou E, Breyne P, et al. (2006). Fine-scale genetic structure and gene dispersal inferences in 10 neotropical tree species. Mol. Ecol. 15: 559-571.http://dx.doi.org/10.1111/j.1365-294X.2005.02785.x

Hastings A, Cuddington K, Davies KF, Dugaw CJ, et al. (2005). The spatial spread of invasions: new developments in theory and evidence. Ecol. Lett. 8: 91-101. http://dx.doi.org/10.1111/j.1461-0248.2004.00687.x

Huang X and Madan A (1999). CAP3: A DNA sequence assembly program. Genome Res. 9: 868-877. http://dx.doi.org/10.1101/gr.9.9.868

Jesus S and Monteiro-Filho ELA (2007). Frugivoria por aves em Schinus terebinthifolius (Anacardiaceae) e Myrsine coriacea (Myrsinaceae). Rev. Bras. Ornitol. 15: 585-591.

Jiménez-Valverde A, Peterson AT, Soberon J, Overton JM, et al. (2011). Use of niche models in invasive species risk assessments. Biol. Invasions 13: 2785-2797. http://dx.doi.org/10.1007/s10530-011-9963-4

Khan IA and Azim MK (2011). Variations in intergenic spacer rpl20-rps12 of mango (Mangifera indica) chloroplast DNA: implications for cultivar identification and phylogenetic analysis. Plant Syst. Evol. 292: 249-255. http://dx.doi.org/10.1007/s00606-011-0424-4

Leimu R and Fischer M (2008). A meta-analysis of local adaptation in plants. PLoS One 3: e4010. http://dx.doi.org/10.1371/journal.pone.0004010

Lenzi M and Orth Al (2004). Caracterização funcional do sistema reprodutivo da aroeiravermelha (Schinus terebinthifolius Raddi), em Florianópolis-SC. Brasil. Rev. Bras. Frutic. 26: 198-201. http://dx.doi.org/10.1590/S0100-29452004000200004

Lenzi M, Orth Al and Laroca S (2003). Associação das abelhas silvestres (Hym., Apoidea) visitantes das flores de Schinus terebinthifolius (Anacardiaceae), na Ilha de Santa Catarina (sul do Brasil). Acta Biol. Parana 32: 107-127.

Lorenzi H (2008). Árvores brasileiras: manual de identificação e cultivo de plantas arbóreas nativas do Brasil. 5th edn. Instituto Plantarum, Nova Odessa.

Mandon-Dalger I, Clergeau P, Tassin J, Riviere JN, et al. (2004). Relationships between alien plants and an alien bird species on Reunion Island. J. Trop. Ecol. 20: 635-642. http://dx.doi.org/10.1017/S0266467404001774

Mukherjee A, Williams DA, Wheeler GS, Cuda JP, et al. (2012). Brazilian peppertree (Schinus terebinthifolius) in Florida and South America: evidence of a possible niche shift driven by hybridization. Biol. Invasions 14: 1415-1430. http://dx.doi.org/10.1007/s10530-011-0168-7

Nath P, Sane AP, Bijola V, Trivedi PK, et al. (1993). A simple method for the purification of organelle DNA of plants. J. Plant Biochem. Biotechnol. 2: 117-120. http://dx.doi.org/10.1007/BF03262937

Petit RJ, Bialozyt R, Garnier-Gere P and Hampe A (2004). Ecology and genetics of tree invasions: from recent introductions to Quaternary migrations. For. Ecol. Manage. 197: 117-137. http://dx.doi.org/10.1016/j.foreco.2004.05.009

Ribeiro DA, Macedo DG, Oliveira LGS, Saraiva ME, et al. (2014). Potencial terapêutico e uso de plantas medicinais em uma área de Caatinga no estado do Ceará, nordeste do Brasil. Rev. Bras. Plantas Med. 16: 912-930. http://dx.doi.org/10.1590/1983-084X/13 059

Ridley M (2006). Evolução. 3rd edn. Artmed: Porto Alegre.

Santos ACA, Rossato M, Agostini F, Santos PL, et al. (2007). Avaliação química mensal de três exemplares de Schinus terebinthifolius Raddi. Rev. Bras. Biocienc. 5: 1011-1013.

Streck NA, Gabriel LF, Heldwein AB, Buriol GA, et al. (2011). Minimum temperature over short grass in Santa Maria, RS: climatology, interannual variability, and historical trend. Bragantia 70: 696-702. http://dx.doi.org/10.1590/S0006-87052011000300028

Sühs RB, Somaville A, Köhler A and Putzke J (2009). Vespídeos (Hymenoptera, Vespidae) vetores de pólen de Schinus terebinthifolius Raddi (Anacardiaceae), Santa Cruz do Sul, RS, Brasil. Rev. Bras. Biocienc. 7: 138-143.

Tang J, Xia H, Cao M, Zhang X, et al. (2004). A comparison of rice chloroplast genomes. Plant Physiol. 135: $412-420$. http://dx.doi.org/10.1104/pp.103.031245

Thompson GD, Robertson MP, Webber BL, Richardson DM, et al. (2011). Predicting the subspecific identity of invasive species using distribution models: Acacia saligna as an example. Divers. Distrib. 17: 1001-1014. http://dx.doi.org/10.1111/j.1472-4642.2011.00820.x

Williams DA, Overholt WA, Cuda JP and Hughes CR (2005). Chloroplast and microsatellite DNA diversities reveal the introduction history of Brazilian peppertree (Schinus terebinthifolius) in Florida. Mol. Ecol. 14: 3643-3656. http://dx.doi.org/10.1111/j.1365-294X.2005.02666.x

Williams DA, Muchugu E, Overholt WA and Cuda JP (2007). Colonization patterns of the invasive Brazilian peppertree, Schinus terebinthifolius, in Florida. Heredity (Edinb) 98: 284-293.http://dx.doi.org/10.1038/sj.hdy.6800936

Yang M, Zhang X, Liu G, Yin Y, et al. (2010). The complete chloroplast genome sequence of date palm (Phoenix dactylifera L.). PLoS One 5: e12762.http://dx.doi.org/10.1371/journal.pone.0012762 